\title{
Organizational and Pedagogical Conditions of Future Social Workers' Professional Training for Social Leadership
}

\author{
Bybyk Daria \\ ORCID ID: $h$ ttp://orcid.org/0000-0001-9947-8503 \\ Postgraduate at the Department of Theory and Technology of Social Work \\ Dragomanov National Pedagogical University (Ukraine, Kyiv)
}

\begin{abstract}
This article is devoted to the study of the need to improve the scientific and methodological support for the professional training of future social workers. Relevance determined the choice of research objectives: to identify the forms and methods of implementing the preparation of future social workers for social leadership.

It was determined that social leadership is the main resource that provides a holistic view of the modern specialist, who should not only be prepared for future professional activity, but also be able to navigate independently in the stream of socio-economic changes, creatively solving professional tasks of social work. Particular attention is concentrated on the features of the use of forms and methods of training social workers. This is noted the prospects of the ideas of social leadership in the development and implementation of the scientific and methodological complex, the success of which is determined by the need to find new ways to improve the quality of theoretical training, the ability to work independently, and professional self-development of students. Non-traditional forms and interactive methods of vocational teaching students provide enhanced training opportunities for social leadership.

Key words: professional training, social worker, social leadership, organisational and pedagogical conditions, non-traditional forms of training, interactive teaching methods.
\end{abstract}

Актуальність дослідження. Сучасна Україна намагається проводити реформи в ситуації постреволюційного суспільства, а також в умовах гібридної війни. Зважаючи, на це, перед професійною підготовкою майбутніх соціальних працівників постає завдання підготувати фахівців здатних до вирішення соціальних проблем, що вимагатиме пошуку шляхів забезпечення максимального прояву особистісного потенціалу та соціального лідерства. Орієнтування на вирішення соціальних проблем та проблем клієнта стає пріоритетним серед різних моделей лідерства, оскільки лідерство узгоджується з цілями і цінностями соціальної робити, які лежать в основі професії «соціальний працівник» [16]. Зокрема, цілі професійної діяльності у соціальній сфері проявляються у змінах, зміщенні, розвитку людини, iï уявлень, розуміння ситуацій, iï практичних уміннях і навичках, набутих у цілеспрямованій діяльності [4; 7; 15; 17].

Об’єктивна соціальна значущість професійної підготовки майбутніх соціальних працівників до соціального лідерства переконливо доводить необхідність пошуку організаційно-педагогічних умов щодо виявлення й удосконалення різних форм і методів 
навчання та виховання, які орієнтовані на особистісний і професійний розвиток, передбачають необхідність актуалізації лідерського потенціалу. Крім того, формування готовності студентів до соціального лідерства має забезпечити реалізацію інноваційних напрямів технологізації професійної діяльності в галузі соціальної роботи.

Професійна підготовка як напрям наукової методології представлено досить поширено у соціально-педагогічних працях та дослідженнях в галузі соціальної роботи (А.Капської, І.Звєрєвої, Л.Міщик, В.Поліщук, С.Харченко, В.Васильєв, Ю.Галагузова, П.Гусак, І.Козубовська, Р.Куличенко, О.Карпенко). Останнім часом форми, методи й технології професійної діяльності у різних осередках соціальної сфери та підготовка майбутніх фахівців до їх застосування розглядалися у дослідженнях І.Дичківської, О.Дубасенюк, С.Коляденко, В.Ковальчук, О.Лісовця, Л.Міщик, Н.Павлік, Р.Петришин, Н.Сейко, Т.Шанскова та ін. Лідерство є темою міжнародних дебатів як в сфері освіти, так і в сфері соціальної роботи. Однак залишаються питання щодо того, які конкретні моделі лідерства слід визначати, і як зміст лідерства повинно бути включено в програму підготовки до соціальної роботи [11].

Загальновідомо, що процес і результат оволодіння цінностями соціальнопедагогічної діяльності, професійно необхідними знаннями, вміннями й навичками, професійно важливими особистісними якостями становлять основу формування готовності до професійної соціально-педагогічної діяльності [9], а процес формування фахівця нового типу, здатного швидко й адекватно реагувати на зміни, що відбуваються в суспільстві сприятиме формуванню компетентності у вирішенні соціальнопедагогічних проблем [5]. Проте, проблема професійної підготовки соціальних працівників до соціального лідерства потребує

спеціального грунтовного вивчення з метою виявлення ефективних форм та методів навчання і виховання майбутніх фахівців.

Виклад основного матеріалу. Стрімкий розвиток фахової підготовки соціальних працівників, зростання значення соціальної роботи щодо подолання суспільних проблем та соціально небезпечних явищ, зумовлює потребу узагальнення тенденцій розвитку як соціальної роботи, так і фахової підготовки соціальних працівників щодо їх впливу на організаційні шляхи реалізації основних напрямів, умов та результатів оновлення змісту, форм та методів навчання [10]. Одним із аспектів, що викликає найбільший інтерес, $є$ 
виявлення, обгрунтування та перевірка умов, які забезпечують успішність здійснюваної діяльності.

Сучасний стан вищої освіти вимагає зосередження уваги на якості професійної підготовки щодо набуття компетенцій майбутніми соціальними працівниками. Тому виникає гостра потреба сформувати лідерів в соціальній сфері, здатних здійснювати професійну діяльність, спрямовану на активізацію особистісного зростання як основи їх життєвого ствердження, реалізації професійного призначення. Оскільки формування готовності майбутніх соціальних працівників до соціального лідерства є динамічним та складним процесом, то його ефективність стає можливою через застосування сукупності організаційно-педагогічних умов професійної підготовки.

3 метою виявлення організаційно-педагогічних умов професійної підготовки майбутніх соціальних працівників було проведено експертне опитування викладачів закладів вищої освіти, які здійснюють професійну підготовку майбутніх соціальних працівників в Україні. Опитування викладачів у якості експертів надало нам можливість визначати важливість та значущість організаційно-педагогічних умов підготовки студентів до соціального лідерства, які були попередньо виділено нами шляхом опрацювання педагогічної та навчально-методичної літератури. Визначення експертами найбільш важливі організаційно - педагогічні умови за п’ятибальною шкалою, забезпечило достатню вірогідність отриманих результатів та надало нам можливість визначити саме ті умови, що мають бути реалізовані в процесі професійної підготовки студентів до соціального лідерства (табл. 1).

Таблиия 1

Визначення значущості організаційно-педагогічних умов підготовки студентів до соціального лідерства

\begin{tabular}{|c|c|c|c|}
\hline \multirow{2}{*}{$\begin{array}{l}\text { № } \\
\text { II/H }\end{array}$} & \multirow{2}{*}{$\begin{array}{c}\text { Організаційно-педагогічні умови } \\
\text { підготовки соціальних працівників }\end{array}$} & \multicolumn{2}{|c|}{ Кількість оцінок } \\
\hline & & абсол. & y\% \\
\hline 1. & $\begin{array}{l}\text { Міжпредметна координація у навчанні професійних } \\
\text { дисциплін та дисциплін загально гуманітарного } \\
\text { циклу }\end{array}$ & 56 & 39,2 \\
\hline 2. & 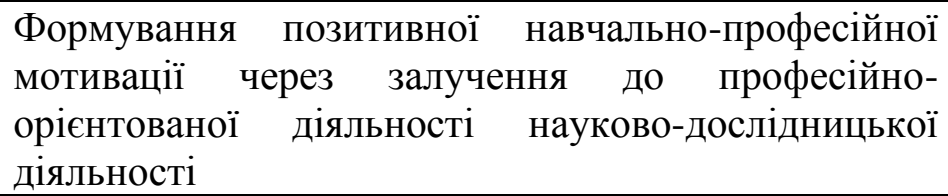 & 61 & 42,7 \\
\hline 3. & $\begin{array}{l}\text { Вдосконалення особистісних і професійних якостей } \\
\text { за допомогою впровадження тренінгової технології }\end{array}$ & 23 & 16,1 \\
\hline
\end{tabular}




\begin{tabular}{|c|c|c|c|}
\hline 4. & $\begin{array}{l}\text { Забезпечення науково-дослідницького змісту } \\
\text { дисциплін фундаментальної, професійної } \\
\text { практичної підготовки соціальних працівників }\end{array}$ & 37 & 25,9 \\
\hline 5. & $\begin{array}{l}\text { Формування мотиваційної основи готовності через } \\
\text { упровадження особистісно орієнтованого навчання }\end{array}$ & 34 & 23,8 \\
\hline 6. & $\begin{array}{l}\text { Імплементація інноваційних } \\
\text { дослідницького, проблемного і саморегульованого) } \\
\text { підходів у освітній процес }\end{array}$ & 21 & 14,7 \\
\hline 7. & $\begin{array}{l}\text { Систематичність, цілеспрямованість, тривалість та } \\
\text { цінність неформального навчання в професійній } \\
\text { підготовці майбутніх фахівців соціальної сфери }\end{array}$ & 56 & 39,2 \\
\hline 8. & 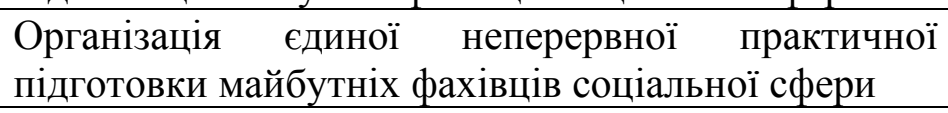 & 5 & 3,5 \\
\hline 9. & 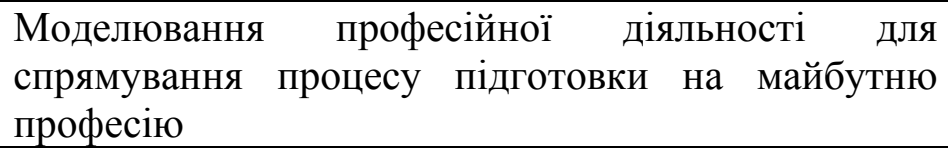 & 9 & 6,3 \\
\hline 10. & $\begin{array}{l}\text { Комплексне використання різних (самостійної, } \\
\text { культурно-дозвіллєвої і волонтерської) видів поза } \\
\text { аудиторної роботи }\end{array}$ & 41 & 28,7 \\
\hline 11. & $\begin{array}{l}\text { Орієнтація на мотиви, інтереси, потреби, установки } \\
\text { учасників неформальної освіти }\end{array}$ & 9 & 6,3 \\
\hline 12. & $\begin{array}{l}\text { Дотримання принципу зв’язку навчання з життям та } \\
\text { практико орієнтованої } \quad \text { місії } \\
\text { навчання }\end{array}$ & 10 & 7 \\
\hline 13. & $\begin{array}{l}\begin{array}{l}\text { Упровадження } \\
\text { технологій }\end{array} \\
\end{array}$ & 53 & 37,1 \\
\hline 14. & $\begin{array}{l}\text { Організація неформальних специфічних структур } \\
\text { середовища підготовки соціальних працівників до } \\
\text { соціального лідерства }\end{array}$ & 87 & 60,9 \\
\hline 15. & $\begin{array}{l}\text { Використання особистісного підходу як базової } \\
\text { ціннісної орієнтації, що визначає стратегію } \\
\text { взаємодії викладача і студента }\end{array}$ & 42 & 29,4 \\
\hline 16. & Розробка навчально-методичного забезпечення & 34 & 23,8 \\
\hline 17. & $\begin{array}{l}\text { Розширення знань } \quad \text { майбутніх соціальних } \\
\text { працівників про сутність соціального лідерства }\end{array}$ & 75 & 52,5 \\
\hline 18. & $\begin{array}{l}\text { Координація методів і технологій формування } \\
\text { професійної комунікативної компетентності }\end{array}$ & 16 & 11,2 \\
\hline 19. & $\begin{array}{l}\text { Систематизація теоретичних знань засобами } \\
\text { інформаційно-комунікативних технологій }\end{array}$ & 8 & 5,6 \\
\hline 20. & 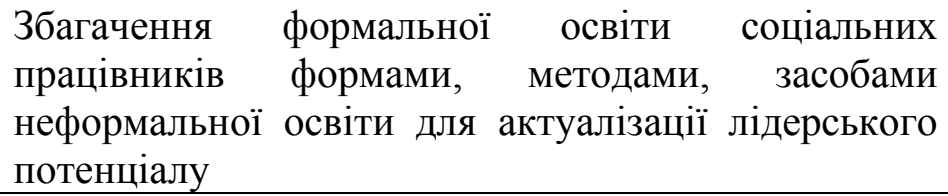 & 82 & 57,4 \\
\hline 21. & $\begin{array}{l}\text { Врахування соціальних } \\
\text { педагогічних папитів } \text { па суходів до вибору змісту, форм і } \\
\text { методів неформальної освіти }\end{array}$ & 12 & 8,4 \\
\hline
\end{tabular}


Спираючись на результати експертного опитування з урахуванням взаємозв'язку сукупності обставин і чинників до організації професійної підготовки майбутніх соціальних працівників було обрано умови, що забезпечать формування готовності студентів до соціального лідерства:

1. Розширення знань майбутніх соціальних працівників про сутність соціального лідерства;

2. Організація неформальних специфічних структур середовища підготовки соціальних працівників до соціального лідерства;

3. Збагачення формальної освіти соціальних працівників формами, методами, засобами неформальної освіти для актуалізації лідерського потенціалу студентів.

Так, дотримання визначених організаційно-педагогічних умов, які розглядаємо враховуючи специфіку формування готовності студентів до соціального лідерства потребує удосконалення форм і методів професійної підготовки майбутніх соціальних працівників.

Першою умовою формування готовності майбутніх соціальних працівників до соціального лідерства є розширення знань про сутність соціального лідерства. Зазначена умова вбирає в себе розробку інтегрованих курсів «Основи лідерства» (90 год. / 3 ECTS) та «Соціальне лідерство» (90 год. / 3 ECTS). Розширення знань про сутність соціального лідерства відбувалося завдяки реалізації нетрадиційних форм та методів організації освітнього процесу підготовки (інтерактивні лекції, дискусії, мультимедійні презентації, обговорення, проектний метод, групова робота, тренінгові вправи, аналіз ситуацій, рольові ігри), що сприяли вдосконаленню змісту підготовки соціальних працівників до соціального лідерства. Забезпечення уявлень про лідерство, види та механізми формування й прояву соціального лідерства передбачало активізацію набутого досвіду студентів через зміну поглядів на роль соціального працівника та збагачення його ціннісних та лідерських орієнтирів.

Щодо умови організації неформальних специфічних структур середовища підготовки соціальних працівників до соціального лідерства, то завдяки іï реалізації забезпечується створення та функціонування «Школи social лідерства - Student», яка розширює можливості неформальної освіти студентів та сприяє розвитку їх лідерського 
потенціалу. Адже упровадження системи неформальної освіти в зміст професійної підготовки майбутніх соціальних педагогів дозволить розширити межі їх професійних, громадянських та особистісних компетенцій за рахунок відповідності сучасних організаційних форм і методів різним рівням впливу на особистість майбутнього фахівця [6]. Залучення студентів до освітньо-тренінгової програми Школи, до її волонтерської, проектної та науково-дослідницької роботи $[8 ; 12 ; 13]$ в галузі соціальної роботи забезпечує активізацію саморозвитку, самовдосконалення та самореалізації шляхом створення соціальних проектів, здійснення власних розробок науково-методичних матеріалів, які допоможуть їм набути необхідних знань для професійного зростання лідерства та реалізації лідерського потенціалу, виявити навички та професійно значущі якості для ефективного лідерства майбутнього соціального працівника.

Важливим аспектом організації формальної освіти соціальних працівників стає їі збагачення формами, методами та технологія навчання та розвитку лідерського потенціалу в умовах неформальної освіти (тренінгове навчання, онлайн-навчання, проектний метод, метод практичних ситуацій, метод тимбілдингу, метод сторітелінгу, арт-коучинг, метод фасилітації «світове кафе», квест-змагання). Отже, студентська молодь, будучи залученою до формальної системи вищої освіти, потребує педагогічної підтримки процесів професійної адаптації та навчальної самореалізації, які успішно забезпечуються організацією неформальної освіти як особливого виду соціальнотехнологічної діяльності, спрямованої на зростання соціального досвіду та забезпечення неперервності в освітньому зростанні учасників [5].

Висновки. Спираючись на зазначене вище, можемо дійти висновку, що формування готовності студентів до соціального лідерства вимагає системного застосування організаційно-педагогічних умов підготовки соціальних працівників. Аналіз психолого-педагогічних джерел та експертне оцінювання організаційнопедагогічних умов підготовки соціальних працівників показав їх важливість щодо цілеспрямованого впливу на якість та результат освітнього процесу. У межах нашого дослідження, виділено та обгрунтовано організаційно-педагогічні умови формування готовності студентів до соціального лідерства у професії «соціальний працівник» до яких, на нашу думку, належать: розширення знань майбутніх соціальних працівників про сутність соціального лідерства; організація неформальних специфічних структур 
середовища підготовки соціальних працівників до соціального лідерства; збагачення формальної освіти соціальних працівників формами, методами, засобами неформальної освіти для актуалізації лідерського потенціалу студентів.

Таким чином, кожна $з$ цих умов відповідає за формування певного структурного компоненту готовності до соціального лідерства, а їх сукупність при цілеспрямованій реалізації в професійній підготовці підпорядкована загальній меті, особливостям актуалізації знань, навичок і вмінь та лідерського потенціалу студентів, що дозволяє створити освітнє середовище прояву соціального лідерства майбутніх соціальних працівників.

\section{References}

1. Bondar T.V. Formuvannya zdorovogo sposobu zhyttya molodi [Formation of the healthy lifestyle of youth] : navch.-metod. posib. dlya pracivny`kiv sluzhb dlya sim»yi ditej ta molodi / T.V.Bondar, O.G.Karpenko, D.M. Dykova-Favors`ka [ta in.]. Kyiv: Ukrayinskyj instytut socialnyh doslidzhen, 2005. $116 \mathrm{p}$.

2. Karpenko O.G. Zmist ta struktura profesijnoyi kompetentnosti socialnogo pracivnyka [Content and structure of professional competence of a social worker]. Socialna pedagogika: teoriya ta prakty`ka. 2006. No. 4. P. 54-59.

3. Karpenko O.G. Motyvaciya v strukturi diyalnosti socialnogo pracivnyka [Motivation in the structure of the social worker]. Socialna robota $v$ Ukrayini: teoriya i praktyka: nauk.-metod. zhurnal. 2011. No. 3-4. P. 16-22.

4. Karpenko O.H. Profesiina diialnist sotsialnoho pratsivnyka yak tvorchyi protses [Professional activity of a social worker as a creative process]. Naukovyi chasopys Natsionalnoho pedahohichnoho universytetu imeni M.P. Drahomanova. Seriia 11. Sotsialna robota. Sotsialna pedahohika.- Vypusk 22: zbirnyk naukovykh prats. Kyiv: Vyd-vo NPU imeni M.P. Drahomanova, 2016. P. 139-145.

5. Mishchyk L.I. Sotsialna pedahohika: dosvid ta perspektyvy [Social pedagogy: experience and prospects]. Zaporizhzhia, 1999. 248 p.

6. Pavlyk N. P. Kontseptsiia vprovadzhennia neformalnoi osvity u protses profesiinoi pidhotovky maibutnikh sotsialnykh pedahohiv [The concept of introducing non-formal education in the process of professional training of future social educators.] Innovatsiina pedahohika. 2018. No.8. P. 163-165.

7. Pet ko L.V., Nikolayenko V.V. Anglijska mova dlya vstupnykiv do magistraturyzi specialnostej: 8.01010601 «Socialna pedagogika», 8.13010201 «Socialna robota» [English for entrants to the master's degree in specialties: 8.01010601 "Social pedagogy", 8.13010201 "Social work"]: navch. posibnyk dlya studentiv, bakalavriv, ta aspirantiv VNZ, 2-ge vyd., dop. i vypr. / za red. O.G.Yaroshenko. Kyiv: «Un-t «Ukrayina», 2011. 152 p.

8. Pet'ko L.V. Zaluchennia studentiv koledzhiv do proektnykh metodyk anhliiskoiu movoiu - odna iz umov neperervnoi osvity [Involving of college students' to project methods in English - one of the conditions for lifelong learning] // Naukova sesiia prysviachena 175-richchiu 
Natsionalnoho ped. un-tu imeni M.P. Drahomanova / upor. L.P.Vovk, O.S.Padalka. Kyiv: Vydvo NPU imeni M.P. Drahomanova, 2010. Knyha 2. P. 383-387.

9. Polishchuk V.A. Profesiina pidhotovka fakhivtsiv sotsialnoi sfery: zarubizhnyi dosvid [Professional training of social specialists: foreign experience] navch. posibnyk. Ternopil: Navchalna knyha - Bohdan, 2003. 184 p.

10. Savelchuk I. B. Pidhotovka sotsialnykh pratsivnykiv za suchasnykh umov: innovatsiini tendentsii [Training of social workers in modern conditions: innovative trends]. Visnyk Zhytomyrskoho derzhavnoho universytetu imeni Ivana Franka . Pedahohichni nauky. 2016. Vol. 1. P. 120-125.

11. Aidyn L. Iachini, Timothy P. Cross \& Darcy A. Freedman. Leadership in Social Work Education and the Social Change Model of Leadership. Journal Social Work Education. 2015. Vol. 34, Issue 6. P. 650-665.

12. Karpenko O.G. Professional functions of social workers as a part of professional competence // Perspective directions of scientific researches: Collection of scientific articles. Agenda Publishing House, Coventry, United Kingdom, 2016. P. 292-294.

13. Karpenko O.G. The formation of professionalism in future social workers in the conditions of higher school // Geopolitical processes in the world today: Collection of scientific articles. - «East West» Association for Advanced Studies and Higher Education. Vienna (Austria). 2016. P. 301-304.

14. Pavlyk N. P. Scientific and methodological instrument for inorgan education in professional preparation of future social pedagoges. Balkan Scientific Review / Balkansko Nauchno Obozrenye, 1, 2018, 64-68. Tsentr, Plovdyv, Blharyia : «Nauchen khronohraf» EOOD.

15. Pet'ko L. Preparing higher school graduates in foreshortening of leader competencies for 2020. Topical questions of contemporary science: Collection of scientific articles. Aspekt Publishing of Budget Printing Center, Taunton, MA 02780, United States of America, 2017. P. 467-472.

16. Sullivan W. Patrick. Leadership in Social Work: Where Are We? Journal of Social Education. 2016. Vol. 52. P. 551-561.

17. Vol'nova Lesya, Zhou Qian. Approaches to upbringing of spiritual culture in Ukrainian and Chinese scientific and educational area. Intellectual Archive. 2016. Volume 5. No. 3 (MayJune). - Toronto : Shiny Word Corp., Canada. PP. 75-85.

Translation of the Title, Abstract and References to the Author's Language

УДК 378: 316.46

Бибик Д. Д. Організаційно-педагогічні умови професійної підготовки майбутніх соціальних працівників до соціального лідерства.

Стаття присвячена дослідженню необхідності вдосконалення науковометодичного забезпечення підготовки майбутніх соціальних працівників. Актуальність визначила вибір цілей дослідження: визначити форми та методи здійснення підготовки майбутніх соціальних працівників до соціального лідерства. Визначено, що соціальне 
лідерство - це ключовий ресурс, який забезпечує цілісний погляд на сучасного фахівця, який повинен не тільки бути готовим до майбутньої професійної діяльності, але й мати можливість самостійно орієнтуватися у потоці соціально-економічних змін, творчо вирішувати професійні завдання соціальної роботи. Особлива увага зосереджена на особливостях використання форм та методів навчання соціальних працівників. Відзначено перспективність ідей соціального лідерства при розробці та впровадженні науково-методичного комплексу, успішність яких визначається необхідністю пошуку нових шляхів підвищення якості теоретичної підготовки, здатності до самостійної творчої роботи, професійному саморозвитку студентів. Розширення можливостей професійної підготовки у соціальному лідерстві забезпечують нетрадиційні форми та інтерактивні методи навчання студентів.

Ключові слова: професійна підготовка, соціальний працівник, соціальне лідерство, організаційно-педагогічні умови, нетрадиційні форми навчання, інтерактивні методи навчання.

Бибик Д. Д. Организационно-педагогические условия профессиональной подготовки будущих социальных работников к социальному лидерству.

Статья посвящена исследованию потребности усовершенствования научнометодического обеспечения профессиональной подготовки будущих социальных работников. Актуальность обусловила выбор целей исследования: обозначить формы и методы реализации подготовки будущих социальных работников к социальному лидерству. Определено, что социальное лидерство выступает тем ключевым ресурсом, который обеспечивает целостное представление о современном специалисте, который должен быть не только подготовленным к будущей профессиональной деятельности, но и уметь самостоятельно ориентироваться в потоке социально-экономических изменений, творчески решая профессиональные задачи социальной работы. Особое внимание сконцентрировано на особенностях использования форм и методов подготовки социальных работников. Отмечено перспективность идей социального лидерства при разработке и внедрении научно-методического комплекса, успешность которых определяется необходимостью поиска новых путей повышения качества теоретической подготовки, способности к самостоятельной творческой работе, профессиональному саморазвитию студентов. Расширение возможностей профессиональной подготовки к социальному лидерству обеспечивают нетрадиционные формы и интерактивные методы обучения студентов.

Ключевые слова. профессиональная подготовка, социальный работник, социальное лидерство, организационно-педагогические условия, нетрадиционные формы обучения, интерактивные методы обучения.

\section{Література}

1. Бондар Т.В. Формування здорового способу життя молоді : навч.-метод. посіб. для працівників служб для сім»ї дітей та молоді / Т.В.Бондар, О.Г.Карпенко, Д.М. Дикова-Фаворська [та ін.]. Київ: Український інститут соціальних досліджень, 2005. $116 \mathrm{c}$.

2. Карпенко О. Зміст та структура професійної компетентності соціального працівника. Соиіальна педагогіка: теорія та практика. 2006. № 4. С. 54-59.

3. Карпенко О.Г. Мотивація в структурі діяльності соціального працівника. 
Соціальна робота в Україні: теорія і практика: наук.-метод. журнал. 2011. № 3-4. C.16-22.

4. Карпенко О.Г. Професійна діяльність соціального працівника як творчий процес. Науковий часопис Національного педагогічного університету імені М.П. Драгоманова. Серія 11. Соціальна робота. Соціальна педагогіка.- Випуск 22: збірник наукових праць. Київ: Вид-во НПУ імені М.П. Драгоманова, 2016. С. 139-145.

5. Міщик Л.І. Соціальна педагогіка: досвід та перспективи. Запоріжжя, 1999. 248с.

6. Павлик, Н.П. Концепція впровадження неформальної освіти у процес професійної підготовки майбутніх соціальних педагогів. Інноваційна педагогіка. 2018. №8. С. 163-165.

7. Петько Л.В., Ніколаєнко В.В. Англійська мова для вступників до магістратури зі спеціальностей: 8.01010601 «Соціальна педагогіка», 8.13010201 «Соціальна робота»: навч. посібник для студентів, бакалаврів, та аспірантів ВНЗ, 2-ге вид., доп. і випр. / за ред. О.Г.Ярошенко. Київ: «Ун-т «Україна», 2011. 152 с.

8. Петько Л.В. Залучення студентів коледжів до проектних методик англійською мовою - одна із умов неперервної освіти // Наукова сесія присвячена 175-річчю Національного педагогічного університету імені М.П. Драгоманова / упор. Л.П.Вовк, О.С.Падалка. Київ: Вид-во НПУ імені М.П. Драгоманова, 2010. Книга 2. С. 383-387.

9. Поліщук В.А. Професійна підготовка фахівців соціальної сфери: зарубіжний досвід: навч. посібник. Тернопіль: Навчальна книга Богдан, 2003. 184 с.

10. Савельчук І.Б. Підготовка соціальних працівників за сучасних умов: інноваційні тенденції. Вісник Житомирського державного університету імені Івана Франка. Педагогічні науки. 2016. Вип. 1. С. 120-125.

11. Aidyn L. Iachini, Timothy P. Cross \& Darcy A. Freedman. Leadership in Social Work Education and the Social Change Model of Leadership. Journal Social Work Education. 2015. Vol. 34, Issue 6. P. 650-665.

12. Karpenko O.G. Professional functions of social workers as a part of professional competence // Perspective directions of scientific researches: Collection of scientific articles. Agenda Publishing House, Coventry, United Kingdom, 2016. P. 292-294.

13. Karpenko O.G. The formation of professionalism in future social workers in the conditions of higher school // Geopolitical processes in the world today: Collection of scientific articles. - «East West» Association for Advanced Studies and Higher Education. Vienna (Austria). 2016. P. 301-304.

14. Pavlyk, N. P. Scientific and methodological instrument for inorgan education in professional preparation of future social pedagoges. Balkan Scientific Review No.1, c. 64-68. Център, Пловдив, България : «Научен хронограф» ЕООД. 2018.

15. Pet'ko L. Preparing higher school graduates in foreshortening of leader competencies for 2020. Topical questions of contemporary science: Collection of scientific articles. Aspekt Publishing of Budget Printing Center, Taunton, MA 02780, United States of America, 2017. P. 467-472.

16. Sullivan W. Patrick. Leadership in Social Work: Where Are We? Journal of Social Education. 2016. Vol. 52. Pp. 551-561. DOI: 10.1080 / 10437797.2016 .1174644

17. Vol'nova Lesya, Zhou Qian. Approaches to upbringing of spiritual culture in Ukrainian and Chinese scientific and educational area. Intellectual Archive. 2016. Volume 5. No. 3 (May-June). - Toronto : Shiny Word Corp., Canada. PP. 75-85. 